\title{
Alteration of fibronectine expression in the kidney extracellular matrix following nicotine administration in gestation and lactation period
}

\author{
Hasan Pahang ${ }^{1 *}$, Mohammad Reza Nikravesh ${ }^{2}$ and Mehdi Jalali ${ }^{2}$ \\ ${ }^{1}$ Department of Anatomy, faculty of medicine, North Khorasan University of Medical Sciences, Bojnord, Iran \\ ${ }^{2}$ Department of Anatomy and Cell Biology, Faculty of Medicine, Mashhad University of Medical Sciences, \\ Mashhad, Iran
}

\begin{tabular}{|l|l|}
\hline $\begin{array}{l}\text { Article history } \\
\text { Received: } 29 \text { Apr, 2016 } \\
\text { Revised: } 5 \text { Jun, 2016 }\end{array}$ & $\begin{array}{l}\text { Abstract } \\
\text { The aim of this study was to assess the effects of maternal nicotine exposure during } \\
\text { pregnancy and lactation periods on fibronectine expression in the extracellular matrix } \\
\text { of kidney of offspring. A total of } 24 \mathrm{female} \text { pregnant Balb/c mice were randomly } \\
\text { divided into four groups as follows: } 3 \mathrm{mg} / \mathrm{kg} / \mathrm{day} \text { nicotine intraperitonealy (IP) from } \\
\text { the } 6^{\text {th }} \text { day of uterine life until the end of pregnancy }(\mathrm{E} 1), 3 \mathrm{mg} / \mathrm{kg} / \mathrm{day} \text { nicotine in a } \\
\text { similar way from the first day of delivery to the end of lactation }(\mathrm{E} 2), 3 \mathrm{ml} / \mathrm{kg} / \mathrm{day} \\
\text { normal saline during pregnancy and lactation period as suggested for E1 and E2. The } \\
\text { results showed that fibronectine reaction was significantly increased in the glomerule } \\
\text { of E1. RT-PCR results demonstrated that the mRNA level of the fibronectin in the E2 } \\
\text { group was up regulated significantly compared to the other group. From the results of } \\
\text { the present study showed that maternal nicotine administration did not alter } \\
\text { fibronectine expression in gestation and lactation life. } \\
\text { Keywords: Maternal nicotine; fibronectine; kidney; extracellular matrix }\end{array}$ \\
\hline
\end{tabular}

\footnotetext{
To cite this article: Pahang H, Nikravesh MR and Jalali M, 2016. Alteration of fibronectine expression in the kidney extracellular matrix following nicotine administration in gestation and lactation period. Res. Opin. Anim. Vet. Sci., 6(5): 138-143.
}

\section{Introduction}

Despite much available information about the deleterious effects of maternal smoking during prenatal and postnatal periods, nearly $20 \%$ of pregnant women continue to smoke during the critical times. Maternal smoking affects the health of both mother and infant (Lim and Sobey, 2011). Many experts have warned about the consequences of passive exposure to smoke for newborn. According to the previous studies, the most effects of maternal cigarette smoking on embryos and newborns include changes in sleep-wake cycle and reduction of iodine supply, intracellular oxidative damage to some organs such as liver, lung and cell death of pancreatic $\beta$ cells (Primo et al., 2013). Also maternal smoking may affect the development and function of other organs. Unfortunately the exact mechanisms of these changes are not clear. Nicotine is the most dangerous chemical agent in cigarette that directly or indirectly affect on tissue cells (Carnevali et al., 2003). Nicotine also affects the gene expression and apoptosis in some tissue (Kawashima et al., 2014). For example, maternal nicotine before birth altered the myelin-related gene expression in the nervous system

*Corresponding author: Hasan Pahang, Department of Anatomy, faculty of medicine, North Khorasan University of Medical Sciences, Bojnord, Iran; E-mail address: Pahang_hasan@yahoo.com;

Tel: +989153152099 
of newborns, moreover, the mRNA of genes that encoding the myelin proteins amplified with age (Zhao et al., 2014). Maternal nicotine exposure during prenatal deregulated adhesion gene expression (Votavova et al., 2012). Fibronectine is one of the most important cell adhesion glycoproteins in the extracellular matrix that interferes with the migration, development and adhesion of various cell types. Also, this molecule is involved in fibrosis of some organs. Any change in synthesis of extracellular matrix such as fibronectine, collagen and other structures leads to imbalance of extracellular matrix components and cell cannot adhere with interstitial matrices produced by cells. For these reasons, the aim of this study was to assess the effects of maternal nicotine administration during pregnancy and lactation periods on fibronectine expression in the offspring kidney extracellular matrix.

\section{Materials and Methods}

The current study was performed in accordance with the rules of the ethics committee for animal experimentation of the Mashhad Medical Sciences University, Iran. A total 24 healthy female mature $\mathrm{Balb} / \mathrm{c}$ mice after confirmed mating were randomly divided into four groups as follow: $3 \mathrm{mg} / \mathrm{kg} /$ day nicotine (Sigma-Aldrich, Saint Louis, USA) via intraperitoneal (IP) injection from the $6^{\text {th }}$ day of embryonic life to the end of pregnancy (E1 group), same dose of nicotine in similar way from the first day of delivery to the end of lactation period ( 20 day), and 3 $\mathrm{ml} / \mathrm{kg} / \mathrm{day}$ normal saline in the same way as suggested for $\mathrm{E} 1$ and $\mathrm{E} 2$ ( $\mathrm{C} 1$ and $\mathrm{C} 2$ respectively). The newborns of all groups were anesthetized by chloroform inhalation at the end of each experimental period. After abdominal incision, their kidneys were removed and transferred to $10 \%$ buffered formalin for immunohistochemical technique and RNA stabilization reagent (RNA later) for Real-time polymerase chain reaction (RT-PCR) technique.

\section{Immunohistochemical (IHC)}

The IHC studies were performed on the right kidney by an indirect immune peroxidase procedure. Briefly, after the kidney tissues were sectioned at $5 \mu \mathrm{m}$ thicknesses, they were deparaffinized and rehydrated then antigen retrieval was performed at $100^{\circ} \mathrm{C}$. To inhibit the endogenous peroxide activity, sections were blocked with $3 \% \mathrm{H}_{2} \mathrm{O}_{2}$ and transferred to phosphatebuffered saline (PBS). Then they were incubated with specific anti-fibronectine primary antibody diluted to 1 in 170 (Abcam, Cambridge, UK) at $4^{\circ} \mathrm{C}$ overnight, followed by staining with horseradish peroxidaseconjugated secondary antibodies. When the slides were exposed to diaminobenzidine (DAB), brown colour appeared. Counterstaining with hematoxylin was performed to clear the cell nuclei. After dehydration and stabilized with mounting medium, the stained sections were examined under a light microscope (Olympus BX51, Japan). The intensity of brown colour showed the level of fibronectine reaction in the renal sections. Image analysis was performed by Quantitative Scoring Methods according to the method of Dixon et al. (1980).

\section{Real-time polymerase chain reaction}

The fibronectine gene expression was performed on the left kidneys with the help of RT-PCR. The kidney samples were homogenized by a laboratory homogenizer (Polytron PT 1200E, Switzerland). Total RNA was extracted from the renal fragments by RNXplus (ParsTous, Tehran, Iran) according to the manufacturer's protocol. The purity of RNA was determined by electrophoresis on an agarose gel. Reverse transcription was performed on $3 \mu \mathrm{g}$ of RNA using a cDNA synthesis kit (ParsTous, Tehran, Iran). The RT- PCR was performed on an ABI PRISM® 48well optical reaction plate (Applied Biosystems Step One, Foster City, USA). The RT-PCR master mix contained $1 \mu \mathrm{l}$ of template (cDNA), $0.2 \mu \mathrm{M}$ forward primer, $0.2 \mu \mathrm{M}$ reverse primer, $3.6 \mu 1$ sterilized water and $5 \mu \mathrm{l}$ SYBR GREEN (ParsTous, Tehran, Iran). The glyceraldehyde-3-phosphate dehydrogenase (GAPDH) gene was used as endogenous gene control. A relative quantification method was used to compare mRNA expression (Livak and Schmittgen 2001). Fold changes in mRNA expression were calculated by using the $2^{-\Delta \Delta \mathrm{ct}}$ equation, where $\triangle \Delta \mathrm{CT}$ is the difference between fibronectine and GAPDH genes expression. Each test was performed in triplicate and the expression level was calculated three times. Amplifications for both genes were performed by an optimized protocol as follow: 10 min at $95^{\circ} \mathrm{C}, 40$ repeated cycles of two steps at $95^{\circ} \mathrm{C}$ for $15 \mathrm{~s}, 58^{\circ} \mathrm{C}$ for $30 \mathrm{~s}, 72^{\circ} \mathrm{C}$ for $30 \mathrm{~s}, 95^{\circ} \mathrm{C}$ for $15 \mathrm{~s}$ and $55^{\circ} \mathrm{C}$ for $1 \mathrm{~h}$.

\section{Oligonucleotide primers}

The sequences of oligonucleotide primers after designing by beacon software were synthesized by oligo macrogen (Seoul, Korea) as follows: Fibronectin forward and reverse primer sequences include 5'taggagaacagtggcagaaag and 5'-ccatcgggactgggttca respectively. Also Gapdh forward and reverse primer sequences was 5'- aactcccattcttccacctttg and 5'tgtagccatattcattgtcataccag.

\section{Statistical analysis}

A t-test analysis was performed for comparing the birth weight and kidney weight between groups and Kruskal-Wallis analysis was used for comparing the nonparametric data between groups in IHC method and the results of RT-PCR were analyzed by one way ANOVA. $\mathrm{P}<0.05$ was measured statistically significant. Values were represented as means \pm SEM. 


\section{Results}

The finding of this research showed that maternal nicotine administration had no effect on the period of gestation in mice and also the mother's body weight almost unchanged after parturition (data not shown). The birth weight and kidney weight of newborns in E1 group reduced significantly $(\mathrm{P}<0.05)$ compared to the C1 newborns, but these values did no change during the lactation period (Table 1). Maternal nicotine in the gestation period decreased the ratio of kidney to body weight significantly $(\mathrm{P}<0.05)$ in comparison to the control group. At the end of lactation period, the newborn kidney/body weight ratio did not change significantly $(\mathrm{P}<0.05)$ compared to the $\mathrm{C} 2$ group newborns.
In IHC method fibronectine positive reaction was observed in brown colour. Evaluation of IHC sections in E1 newborns showed Fibronectine reaction was significantly $(\mathrm{P}<0.05)$ increased in the glomerule versus to the normal saline-treated control. Also the internal diameter of convoluted tubule reduced in E1 group newborns compared to $\mathrm{C} 1$ group. Moreover, degenerative alteration observed in the epithelium of some cases in the E1 and E2 newborns kidney tubules. Therefore, this finding improved that maternal nicotine increased the accumulation of extracellular matrix component in the interstitial space between the renal convoluted tubules (Fig. 1). But these changes were not seen in the kidney sections of mice that received normal saline. On the other hand, the glomerular size decreased significantly in the nicotinic mice offspring groups in comparison with control group (Fig. 2).
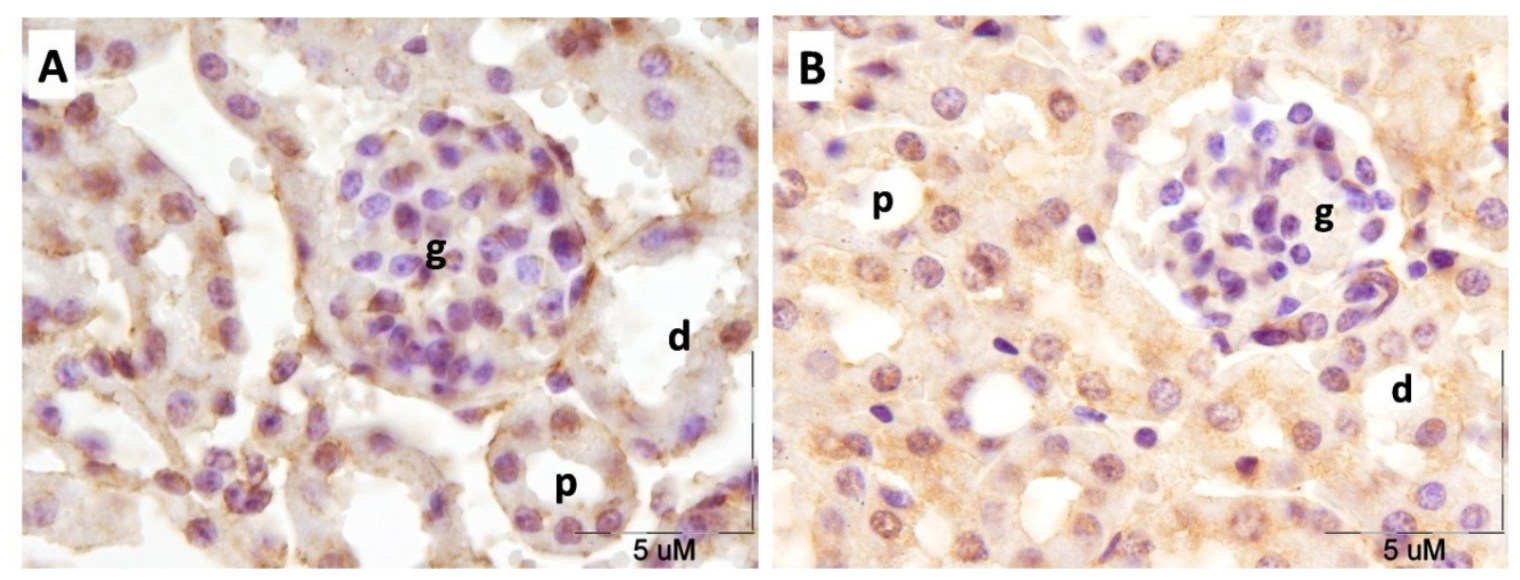

Fig. 1: Effects of maternal nicotine on fibronectine expression in newborn kidney (A) Immunohistochemical stained section in control group showing homogeneous weakly fibronectin reaction in the mesangium extracellular space. (B) Immunoreactions for fibronectin in nicotinic group showed intermediate reaction in the glomerular (g) and tubular (p, d) mesangial space than the control.
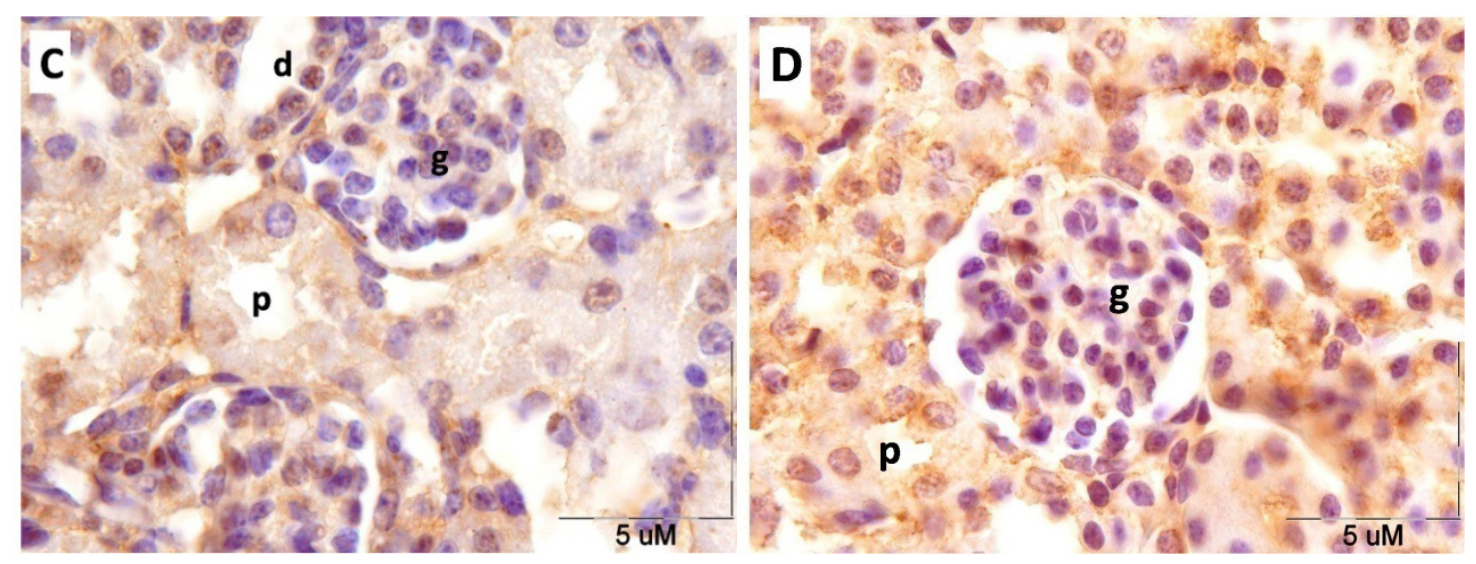

Fig. 2: Immunohistochemical staining for fibronectine reaction in kidney of mice at the end of lactation period (C) Immunohistochemistry staining for fibronectin at the lactation end of control group showing positive moderate staining in the glomerule (g) and interstitial space (D) Immunohistochemistry staining for fibronectin in the nicotinic mice shows a distended glomerulus (g) and strong positivity reaction in extracellar tubular matrix. 


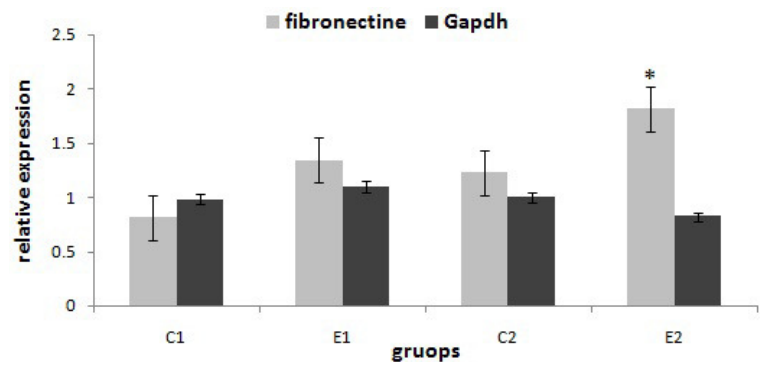

Fig 3: The mRNA expression of fibronectin was analyzed in the offspring kidney tissues. RT-PCR analysis demonstrated that maternal nicotine during lactation significantly increased the mRNA expression of fibronectin whereas maternal nicotine during gestation unchanged it. The data are presented as means $\pm \mathrm{SD} ; * \mathbf{P}<0.05$ between the E2 and other groups.

Table 1: Comparison of the body weight, kidney weight, and the kidney to body weight ratio in the offspring of mice that received nicotine or normal saline during gestation and lactation period

\begin{tabular}{cccc}
\hline $\begin{array}{c}\text { Group } \\
\text { newborns }\end{array}$ & $\begin{array}{c}\text { body } \\
\text { weight }(\mathrm{g})\end{array}$ & $\begin{array}{c}\text { kidney } \\
\text { weight }(\mathrm{g})\end{array}$ & $\begin{array}{c}\text { kidney/body } \\
\text { ratio\% }\end{array}$ \\
\hline C1 & $1.65 \pm 0.128$ & $0.0038 \pm 0.00024$ & $1.058 \pm 0.301$ \\
E1 & $1.16 \pm 0.098$ & $0.0046 \pm 0.00041$ & $1.425 \pm 0.18^{*}$ \\
C2 & $8.32 \pm 0.3$ & $0.127 \pm 0.049$ & $1.065 \pm 0.402$ \\
E2 & $5.51 \pm 0.41$ & $0.091 \pm 0.065$ & $1.425 \pm 0.18$ \\
\hline
\end{tabular}

Values were represented as means \pm SEM. $* \mathrm{P}<0.05$ between the $\mathrm{E} 1$ and $\mathrm{C} 1$ groups

In agreement with the immunohistochemical staining, our quantitative RT-PCR results demonstrated that the fibronectine expression related to Gapdh in experimental groups was changed in the gestation and lactation period. The mRNA level of the fibronectin in the E2 group was up regulated significantly $(\mathrm{P}<0.05)$ compared to the other groups, whereas mRNA level of the fibronectin did not affect following to maternal nicotine in the gestation period (Fig. 3).

\section{Discussion}

The present study showed that maternal nicotine treatment during pregnancy reduced the kidney weight to body weight ratio and increased the expression of fibronectin of extracellular matrix in the kidney during lactation. Extensive investigations have shown that fibronectine has an important role in cell adhesion, proliferation, migration, and cellular differentiation during development process. The potential adverse effect of the Nicotine in breast milk on the newborn tissues depends not only on the amount of nicotine consumed by the mother but also on the period of breast feeding. Nicotine after absorbed in the intestine of newborn is mainly metabolized by the hepatocytes before the entrance to the systemic circulation and then may be accumulated in some tissues (Bruin et al., 2007). Özokutan study showed that maternal nicotine during lactation did not alter any histopathological appearance of kidney in rat offspring, but unexpectedly induced local necrosis and hepatocytes degeneration in the liver and increased oxidative stress (Özokutan et al., 2005). It is important to consider the developmental process in different species. However, our study was performed on mice offspring and there were conflicting results according to the present study. Another study showed that maternal nicotine exposure during prenatal and postnatal period caused cell death in some organs. Nicotine exposure during embryonic life or during lactation did not cause any permanent damage (Bruin et al. 2007). This finding is comparable to the present study and our results confirmed.

Obert and college proved that nicotine induces mesangial cell division and cause fibronectin accumulation in the extracellular matrix and may be progressed diabetic nephropathy (Obert et al., 2011). Some investigation demonstrated nicotine during pregnancy increased the rate of inflammatory markers such as TGF $\beta$ glomerular expression among offspring after delivery (Block et al., 2015). Presumably the cooperation of Connective-Tissue Growth Factor with TGF $\beta-1$ induces the expression of extracellular matrix components (Mendes et al., 2015). So kidney fibroblasts that synthesis high levels of fibronectine mRNA activate with TGF $\beta$ (Mohsenzadeh et al., 2014). Also maternal nicotine administration during prenatal and postnatal induces epithelium to mesenchym transformation and cause fibrosis in offspring organs (Chen et al., 2015). Moreover, fibronectin up regulation involved kidney development and intrinsically related to the kidney fibrotic disorder. TGF- $\beta 1$ significantly increased both mRNA and fibronectin protein expression in other word inhibition of TGF- $\beta 1$ attenuated fibronectin production. According to Liu et al. (2014) the mesangial cell regulated fibronectin production by caveolin-1 phosphorylation. Kidney disease such as fibronectin glomerulopathy and fibrillary glomerulonephritis followed by alteration in glomerular basement membrane structure and other extracellular components leading to weaker and easily extracellular ruptured structures (Yuste et al., 2015). Therefore, fibronectine deregulation in the interstitial space causes imbalance between soluble and insoluble fibronectin leading to fibronectin glomerulopathy, although the prevalence rate is higher in adolescence (Deltas et al., 2012). Current research too showed that exposure to nicotine through breastfeeding increases the fibronectine accumulation in kidney offspring. Researchers' indicated that the level of nicotine in breast milk is 2.9 times higher than the level in blood plasma and the amount of cotinine excreted in the urine 
by kidneys was about ten times higher in newborn feeding by breast smoking that is similar to adult smokers. For these reasons, breastfeeding increases the exposure to tobacco metabolites especially nicotine (Mascola et al., 1998). Nicotine through interaction with the nicotinic acetylcholine receptors (nAChRs) in the plasma membrane, facilitates the entrance of calcium ion into a series of downstream signalling that affects modulation of the cells microenvironment and changing the functions of fibroblasts in this way and modulates fibrosis in some organs (Schuller, 2009). Also, nicotine damaged kidney tubules epithelium due to the imbalance of $\mathrm{Na}^{+}$and $\mathrm{Cl}^{-}$transport that was associated with changes in the morphological appearance in a mouse model (Arany et al., 2011). Another study showed that nicotine increased the expression of epithelial-mesenchymal transition markers such as vimentin and fibronectin in the renal epithelium (Arany et al., 2012).

Nicotine also regulates the gene expression of mice in some tissue, for example, one study demonstrated that nicotine increased the expression of TGF- $\beta 1$, which was responsible for the induction of fibronectin synthesis in mouse kidney (Arany et al., 2012). Another study proved that every dose of nicotine in vitro increased gene expression and protein synthesis (Armstrong et al., 1996).

Many studies have reported contradictory results in the weight of offspring in maternal nicotine treatment. According to the previous studies, maternal nicotine induced adiposynthesis in rats' offspring and increased protein body level compared with control, however, maternal nicotine unchanged offspring body weight during lactation period (Bruin et al., 2007). Even though the exact mechanism of fibronectine accumulation was not well understood the nicotine may be directly interacting with alpha $7 \mathrm{nAChR}$ to induce fibronectine accumulation following uterus nicotine exposure. Maternal nicotine during gestation and lactation increases the connective tissue growth factor (CTGF) in the renal epithelium and causes epithelium to mesenchym transition, consequently, tubular injury was significantly higher in nicotine-treated offspring than the control. Also further analyses verified the occurrence of kidney fibrosis. These results may be related to low-birth-weight infants who are exposed to breast milk of smoking mothers during the neonatal period (Chen et al., 2014). In uterus, nicotine exposure considerably increased both airway thickness and elastin mRNA expression in lungs of Rhesus monkeys, but protein expression in parenchyma did not change (Sekhon et al., 2002). Damage to the epithelial/endothelial bed stimulates the fibrosis process by releasing transforming growth factor- $\beta 1$ (TGF- $\beta 1$ ), production of reactive oxygen species (ROS) and activation of fibroblast in the renal mesangium. The most important factor in the synthesis of ROS is the production of superoxide by nicotinamide adenine dinucleotide phosphate (NADPH) oxidase in mesangial cells (Kisseleva and Brenner, 2008).

\section{Conclusion}

Maternal nicotine exposure did not alter fibronectine expression of extracellular matrix in kidney of mice during maternal and lactation life.

\section{Acknowledgements}

This research was supported by Mashhad medical science university of Iran according to the Research Project Grant Number 900629. I wish to thank my dear colleagues Shahriar Ahmadpour for his helpful discussion on various aspects of cell biology and giving me extremely useful suggestions.

\section{References}

Arany I, Grifoni S, Clark JS, Csongradi E, Maric C, Juncos LA (2011) Chronic nicotine exposure exacerbates acute renal ischemic injury. Amer J Physiol-Renal Physiol 301: 125-133.

Arany I, Reed DK, Grifoni SC, Chandrashekar K, Booz GW, Juncos LA (2012) A novel U-STAT3dependent mechanism mediates the deleterious effects of chronic nicotine exposure on renal injury. Amer J Physiol-Renal Physiol 302: 722729.

Armstrong LA, Rom WN, Martiniuk FT, Hart D, Jagirdar J, Galdston M (1996) Nicotine enhances expression of the neutrophil elastase gene and protein in a human myeloblast/promyelocyte cell line. Amer J Respir Critical Care Med 154: 15201524.

Block DB, Mesquita FF, de Lima IP, Boer PA, Gontijo JA (2015) Fetal kidney programming by maternal smoking exposure: effects on kidney structure, blood pressure and urinary sodium excretion in adult offspring. Nephron 129: 283-292.

Bruin JE, Kellenberger LD, Gerstein HC, Morrison KM, Holloway AC (2007) Fetal and neonatal nicotine exposure and postnatal glucose homeostasis: identifying critical windows of exposure. J Endocrinol 194: 171-178.

Carnevali S, Petruzzelli S, Longoni B, Vanacore R, Barale R, Cipollini M, Scatena F, Paggiaro P, Celi A, Giuntini C (2003). Cigarette smoke extract induces oxidative stress and apoptosis in human lung fibroblasts. Am J Physiol Lung Cell Mol Physiol 284: 955-963.

Chen C, Chou H, Huang L (2014) Maternal nicotine exposure during gestation and lactation induces kidney injury and fibrosis in rat offspring. Pediatric Res 77: 56-63. 
Chen C, Chou H, Huang L (2015) Maternal Nicotine Exposure Induces Epithelial-Mesenchymal Transition in Rat Offspring Lungs. Neonatology 108: 179-187.

Deltas C, Pierides A, Voskarides K (2012) The role of molecular genetics in diagnosing familial hematuria(s). Pediatr Nephrol 27: 1221-1231.

Dixon AJ, Burns J, Dunnill MS, McGee JO (1980) Distribution of fibronectin in normal and diseased human kidneys. J Clin Pathol 33: 1021-1028.

Kawashima A, Koide K, Ventura W, Hori K, Takenaka S, Maruyama D, Matsuoka R, Ichizuka K, Sekizawa A (2014) Effects of maternal smoking on the placental expression of genes related to angiogenesis and apoptosis during the first trimester. PLoS One 9: 106140.

Kisseleva T, Brenner D (2008) Mechanisms of fibrogenesis. Experim Biol Med 233: 109-122.

Lim R, Sobey C (2011) Maternal nicotine exposure and fetal programming of vascular oxidative stress in adult offspring. Br J Pharmacol 164: 1397-1399.

Liu Y, Lu S, Zhang Y, Wang X, Kong F, Liu Y, Peng L, Fu Y (2014) Role of caveolae in high glucose and TGF-beta(1) induced fibronectin production in rat mesangial cells. Int J Clin Exp Pathol 7: 83818390.

Livak K, Schmittgen T (2001). Analysis of relative gene expression data using real-time quantitative PCR and the 2(-Delta Delta C(T)) Method. Methods 25: 402-408.

Mascola M, Van Vunakis H, Tager I, Speizer F, Hanrahan J (1998) Exposure of young infants to environmental tobacco smoke: breast-feeding among smoking mothers. Am J Public Health 88: 893-896.

Mendes F, Coelho Aguiar J, Kahn S, Reis A, Dubois L, Romão L, Ferreira L, Chneiweiss H, Moura Neto V, Abreu J (2015) Connective-Tissue Growth Factor (CTGF/CCN2) Induces Astrogenesis and
Fibronectin Expression of Embryonic Neural Cells In Vitro. PLoS One 10: 0133689.

Mohsenzadeh Y, Rahmani A, Cheraghi J, Pyrani M, Asadollahi K (2014) Prenatal exposure to nicotine in pregnant rat increased inflammatory marker in newborn rat. Mediators Inflamm 2014: 274048.

Obert D, Hua P, Pilkerton M, Feng W, Jaimes E (2011) Environmental tobacco smoke furthers progression of diabetic nephropathy. Am J Med Sci 341: 126130.

Özokutan B, Özkan K, Sarı İ, Inanç F, Güldür M, Kılınç M (2005). Effects of maternal nicotine exposure during lactation on breast-fed rat pups. Neonatology 88(2): 113-117.

Primo C, Ruela P, Brotto L, Garcia T, Lima Ede F (2013) Effects of maternal nicotine on breastfeeding infants. Rev Paul Pediatr 31: 392-397.

Schuller H (2009) Is cancer triggered by altered signalling of nicotinic acetylcholine receptors? Nat Rev Cancer 9: 195-205.

Sekhon H, Keller J, Proskocil B, Martin E, Spindel E (2002) Maternal Nicotine Exposure Upregulates Collagen Gene Expression in Fetal Monkey Lung: Association with $\alpha 7$ Nicotinic Acetylcholine Receptors. American J Respir Cell Mol Biol 26: 31-41.

Votavova H, Dostalova Merkerova M, Krejcik Z, Fejglova K, Vasikova A, Pastorkova A (2012) Deregulation of gene expression induced by environmental tobacco smoke exposure in pregnancy. Nicotine Tob Res 14: 1073-1082.

Yuste C, Gutierrez E, Sevillano A, Rubio-Navarro A, Amaro-Villalobos J, Ortiz A (2015) Pathogenesis of glomerular haematuria. World J Nephrol 4: 185195.

Zhao S, Cui W, Cao J, Luo C, Fan L, Li M (2014) Impact of maternal nicotine exposure on expression of myelin-related genes in zebrafish larvae. Zebrafish 11: 10-16. 